\title{
Impact of Front Line Demonstration to Transfer of Technology in Green Gram
}

\author{
Yamini Raut ${ }^{1 *}$, Anil K. Mishra ${ }^{2}$ and Sunita Napit ${ }^{3}$
}

${ }^{1}$ Sher-e-Kashmir University Agricultural Science and Technology-Jammu, Jammu \& Kashmir, India

${ }^{2}$ R.A.K. College of Agriculture, Sehore, Madhya Pradesh, India

${ }^{3}$ Govt. College Baldevgarh, Tikamgarh, Madhya Pradesh, India

*Corresponding author: yaminiraut1992@gmail.com (ORCID ID: 0000-0002-8353-6892)

Received: 06-04-2021

Revised: 08-06-2021

Accepted: 15-07-2021

\begin{abstract}
Front line demonstration is an appropriate means for demonstration as well as the transfer of improved agricultural innovation to the farming community. Krishi Vigyan Kendra Shajapur has conducted a front line demonstration in farmer's field during 2013-14 to 2018-19, in all 45 demonstrations on the Green gram to transfer the latest technology among the farmers of Shajapur district. The result revealed that the highest green gram yield was obtained in demonstrated plot with an average of $7.98 \mathrm{qt} / \mathrm{ha}$ compared to $5.89 \mathrm{qt} / \mathrm{ha}$ in farmer's practice. Higher average net return (₹ 33274/ha) was obtained in the demonstration plots compared to farmers' practice plot ( $₹ 23003.66 /$ ha). The average B:C ratio was calculated 3.39 in demonstrated plot compared to 2.77 in farmer's plot. This can be attributed to improved technology as well as improved varieties. The yield level was considerably low under local practices because of considerable variation in the extent of adoption of recommended practices depending upon the amount of risk involved in terms of cost convenience, skill and knowledge about the concerned practices. The productivity was better over local practices under demonstration. Hence, Green gram production technology has a broad scope for increasing the area and production of Green gram.

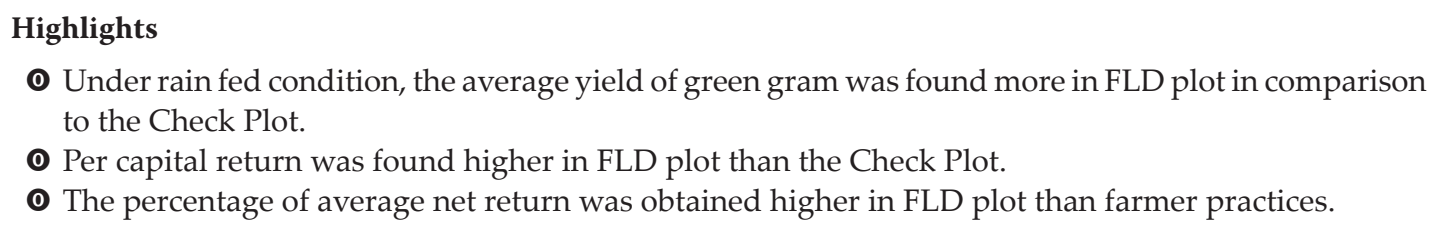

Keywords: Front line demonstration, technology gap, technology Index, cost of cultivation, green gram

According to the nutritionist, pulses are an excellent source of dietary and can play an important role of fulfilling requirement of rapidly increasing population. India, with a share of 22 percent, is the largest producer of pulses in the world (Sangeetha et al. 2020). Green gram is an important pulse crop that can be grown twice a year i.e. Kharif and Zaid season. Among the grain legumes it is one of the important crop of India. Its seed are more palatable, nutritive, digestible and non-flatulent than other pulses grown in the country. Green gram contains $24.7 \%$ protein, $0.6 \%$ fat, $0.9 \%$ fiber and $3.7 \%$ ash.
Besides being a rich source of protein, it maintains soil fertility through biological nitrogen fixation in soil and thus plays a vital role in sustainable agriculture.

In India the area of green gram was 38.32 lakh ha in 2018-19 with production 17.84 lakh ton and productivity of $488 \mathrm{~kg} / \mathrm{ha}$. Production of pulses in India is far below the requirement to meet even

How to cite this article: Raut, Y., Mishra, K.A. and Napit, S. (2021). Impact of Front Line Demonstration to Transfer of Technology in Green Gram. Economic Affairs, 66(2): 299-304.

Source of Support: None; Conflict of Interest: None 
than minimum level per capital consumption. It is necessary to popularize improved agricultural technology on farmer's field to increase production of pulses to meet the requirement of increasing population of the country. The aim of the front line demonstration is to convey the technical message to farmers, that with the use of recommended package and practices the yield of this crop can be easily doubled than their present level.

The most feasible way by which this could be achieved is by demonstrating the recommended improved technology on the farmer's fields through front line demonstration with the objective to work out the input cost and monetary returns between front line demonstrations and farmer's methods and to identify the yield gaps between farmer's practices and front line demonstrations.

\section{MATERIALS AND METHODS}

The technologies to be demonstrated for green gram were identified based on Participatory Rural Approach (PRA) technique. A group of co-operative farmers were identified based on their participation and feedback received during the preliminary survey and interactive meeting. Front line demonstrations were conducted by the Krishi Vigyan Kendra Shajapur Madhya Pradesh in Kharif seasons in the farmer's field of Shajapur district during 2013-14 to 2018-19. All 45 demonstrations were conducted by the active participation of farmers with the objective to demonstrate the improved technologies of pulses production potential in different villages.

A total area of 2 to 4 hectare in every year was fixed for the demonstration of technology in green gram along with farmer practice as control plot. Pre-sowing training were organized involving the selected farmers in their village for the crop critical inputs for the technologies to be demonstrated
(Table 1) were distributed to the farmers after the training like improved high yielding variety ,recommended chemical, other literature, regular visit , monitoring, pest and disease advisory services management by KVK scientist to the demo farmers. Finally field day was conducted ATARI, officials from Department of Agriculture and local extension functionaries to demonstrate the superiority of each technology for green gram crop. Crop yield was recorded from the demonstration and control plot for the crops at the time of harvesting.

The yield data were collected from the demonstrations and farmers practice by random crop cutting method and analysis was done by using simple statistical tools. The technology gap, technological index, farm profitability and $\mathrm{B}$ : $\mathrm{C}$ ratio was calculated by using the formula as given below:

1. Technology gap = Potential yield Demonstration yield

2. Technology Index $=$

Potential yield - Demonstration yield Potential yield

3. Percent increase $=$ $\frac{\text { Demonstration yield }- \text { farmers yield }}{\text { Farmers yield }} \times 100$

4. For estimation of cost of cultivation, Cost concepts were used

5. Net Farm Income $=$ Gross income - Cost ' $\mathrm{C} 3$ '

6. Benefit Cost Ratio $=$ Gross income $/$ Total expenses (Cost C3)

\section{RESULTS AND DISCUSSION}

Table 2 shows that the average yield recorded in green gram under rain fed situation was ranged 5.31 to $10.2 \mathrm{qt} / \mathrm{ha}$ with an average of $7.98 \mathrm{qt} / \mathrm{ha}$ in FLD plots which was more than check plot wherein,

Table 1: Differences between technology intervention and farmer practices under FLD on Green gram

\begin{tabular}{|l|l|l|l|}
\hline Particulars & Technological intervention in FLD & Farmer practices & Gap \\
\hline Variety & TJM-3,JM721 & Local/own seed & Full gap \\
\hline Seed rate & 15-20 kg/ha & 20-25 kg/ha & High seed rate \\
\hline Seed treatment & $\begin{array}{l}\text { Carbendazim @2g.Imimdacloprid @5mi/kg seed } \\
\& \text { Rhizobium @500g/ha seed }\end{array}$ & No seed treatment & Full gap \\
\hline Fertilizer dose & 25kg Urea\&300kg SSP & No use of fertilizer & Full gap \\
\hline Weed management & $\begin{array}{l}\text { Pendimithalin@2.5 L/ha and one hand weeding } \\
@ 30-45 \text { days }\end{array}$ & Pendimithalin@2.5L/ha & Partial gap \\
\hline Plant protection & Need base timely spraying & Improper measures & Full gap \\
\hline
\end{tabular}


Table 2: Performance of Green Gram under Front Line Demonstration and Farmers Practices during Kharif 201314 to 2018-19 (Pooled Data)

\begin{tabular}{|c|c|c|c|c|c|c|c|c|c|c|c|}
\hline \multirow[t]{2}{*}{ Year } & \multirow{2}{*}{$\begin{array}{l}\text { Demo } \\
\text { Variety }\end{array}$} & \multirow{2}{*}{$\begin{array}{l}\text { No. of } \\
\text { Demos }\end{array}$} & \multirow{2}{*}{$\begin{array}{l}\text { Area } \\
\text { (Ha.) }\end{array}$} & \multicolumn{2}{|c|}{$\begin{array}{l}\text { Yield } \\
\text { (qt/ha) }\end{array}$} & \multirow{2}{*}{$\begin{array}{l}\% \text { increase } \\
\text { - over Check }\end{array}$} & \multicolumn{2}{|c|}{ B:C Ratio } & \multirow{2}{*}{$\begin{array}{l}\text { Potential } \\
\text { - Yield (qt/ha.) }\end{array}$} & \multirow{2}{*}{$\begin{array}{l}\text { Technology } \\
\text { gap (qt/ha) }\end{array}$} & \multirow{2}{*}{$\begin{array}{l}\text { Technology } \\
\text { index (\%) }\end{array}$} \\
\hline & & & & Demo & Check & & Demo & Check & & & \\
\hline 2013-14 & TJM-3 & 5 & 2 & 8.20 & 5.80 & 41.4 & 1.95 & 1.52 & 12.0 & 3.80 & 31.6 \\
\hline 2014-15 & TJM-3 & 5 & 2 & 6.48 & 4.48 & 44.6 & 4.01 & 3.06 & 12.0 & 5.52 & 46.00 \\
\hline 2015-16 & JM-721 & 5 & 2 & 9.20 & 6.9 & 33.3 & 2.52 & 2.30 & 11.0 & 1.80 & 16.36 \\
\hline 2016-17 & TJM-3 & 10 & 2 & 8.5 & 5.4 & 57.40 & 4.20 & 3.37 & 12.0 & 3.50 & 29.16 \\
\hline 2017-18 & TJM-3 & 10 & 2 & 5.31 & 4.20 & 26.42 & 3.14 & 2.70 & 12.0 & 6.69 & 55.75 \\
\hline 2018-19 & TJM-3 & 10 & 2 & 10.2 & 8.6 & 18.60 & 4.52 & 3.72 & 12.0 & 1.80 & 15.00 \\
\hline Average & & & & 7.98 & 5.89 & 35.48 & & & & & \\
\hline
\end{tabular}

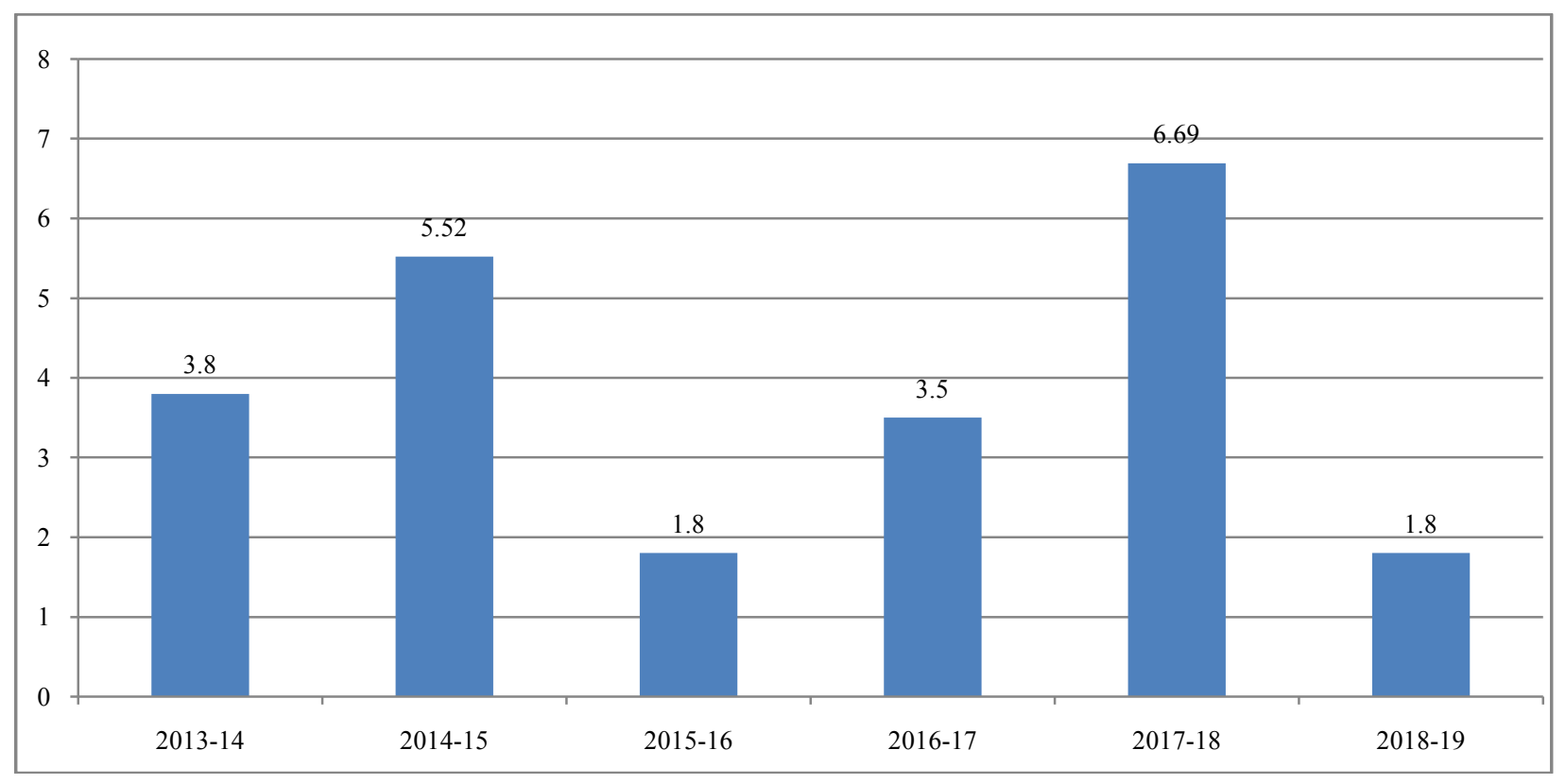

Fig. 1: Year wise technological gap (qt/ha.)

the yield was varied from 4.2 to $8.6 \mathrm{qt} / \mathrm{ha}$ with an average of $5.89 \mathrm{qt} / \mathrm{ha}$. The results indicated that the front line demonstration gave good impact over the farming community of Shajapur district as they were motivated by new agricultural technologies applied in the FLD plots. The fluctuations in over all yield of green gram from 2013-14 to 2018-19 was due to the YMV and weather condition in Shajapur district. The yield of demonstrated plots over check plots was found $41.4 \%$ in $2013-14,44.6 \%$ in $2014-15$, 33.3 in $2015-16,57.40 \%$ in $2016-17,26.42$ in $2017-$ 18 and 18.60 in 2018-19. The average percentage increased in yield of demonstrated plots was $35.48 \%$ over check plots.

Yield data and economic parameter are presented in Table 3. The result reveled that yield of green gram was considerably more under demonstration plot as compared to check plot in years 2013-14 to 2018-19. The yield of green gram under demonstration plot was received as $8.20,6.48,9.20,8.50,5.31$ and 10.2 qt/ha in 2013-14, 2014-15, 2015-16, 2016-17, 2017-18 and 2018-19 respectively. Improvement in yield due to technology intervention was 41.4, 44.64, 33.33, 57.40, 26.42 and 18.60 percent higher as compared to control. The pronounced influence of adoption of technologies over five years gave the yield of $7.98 \mathrm{qt} / \mathrm{ha}$ which was $38.63 \%$ more as compared to local check. It might be due to various factors like social and economic conditions and prevailing microclimatic condition which affect the yield of this crop. It is also confirmed by other workers that identification, farming situation and intervention have great importance to enhance the productivity under demonstration has also supported by various 
Table 3: Performance of improve technologies of Green Gram cultivation on production through demonstration

\begin{tabular}{|c|c|c|c|c|c|}
\hline \multirow{3}{*}{ Year } & \multirow{3}{*}{ Variety } & \multicolumn{2}{|c|}{ Seed yield (qt/ha) } & \multirow{3}{*}{$\begin{array}{l}\text { - Additional yield over } \\
\text {-farmers practices (qt/ha) }\end{array}$} & \multirow{3}{*}{$\begin{array}{l}\text { Increase over Farmers } \\
\text { practices }(\%)\end{array}$} \\
\hline & & Improve technology & Farmer practices & & \\
\hline & & Maximum & Mean & & \\
\hline 2013-14 & TJM-3 & 8.20 & 5.80 & 2.40 & 41.40 \\
\hline 2014-15 & TJM-3 & 6.48 & 4.48 & 2.00 & 44.64 \\
\hline 2015-16 & JM-721 & 9.20 & 6.90 & 2.30 & 33.33 \\
\hline 2016-17 & TJM-3 & 8.50 & 5.40 & 2.30 & 57.40 \\
\hline 2017-18 & TJM-3 & 5.31 & 4.20 & 1.11 & 26.42 \\
\hline 2018-19 & TJM-3 & 10.20 & 8.60 & 1.6 & 18.60 \\
\hline Mean & & 7.98 & 5.89 & 2.09 & 35.48 \\
\hline
\end{tabular}

Table 4: Economic evaluation of improve technology of Green Gram cultivation

\begin{tabular}{lllll}
\hline Particular & $\begin{array}{l}\text { Improved } \\
\text { practices }\end{array}$ & $\begin{array}{l}\text { Farmers } \\
\text { practices }\end{array}$ & $\begin{array}{l}\text { Actual increase practices } \\
\text { over Farmers }\end{array}$ & $\begin{array}{l}\text { Increase over } \\
\text { Farmer practices(\%) }\end{array}$ \\
\hline Average yield $(\mathrm{kg} / \mathrm{ha})$ & 7.98 & 5.89 & 2.08 & 35.48 \\
Cost of cultivation $(₹ / \mathrm{ha})$ & 12233 & 9258.33 & 2974.67 & 32.12 \\
Net return $(₹ / \mathrm{ha})$ & 33274 & 23003.66 & 10270.34 & 44.64 \\
B:C Ratio & 3.39 & 2.77 & 0.62 & 22.38 \\
\hline
\end{tabular}

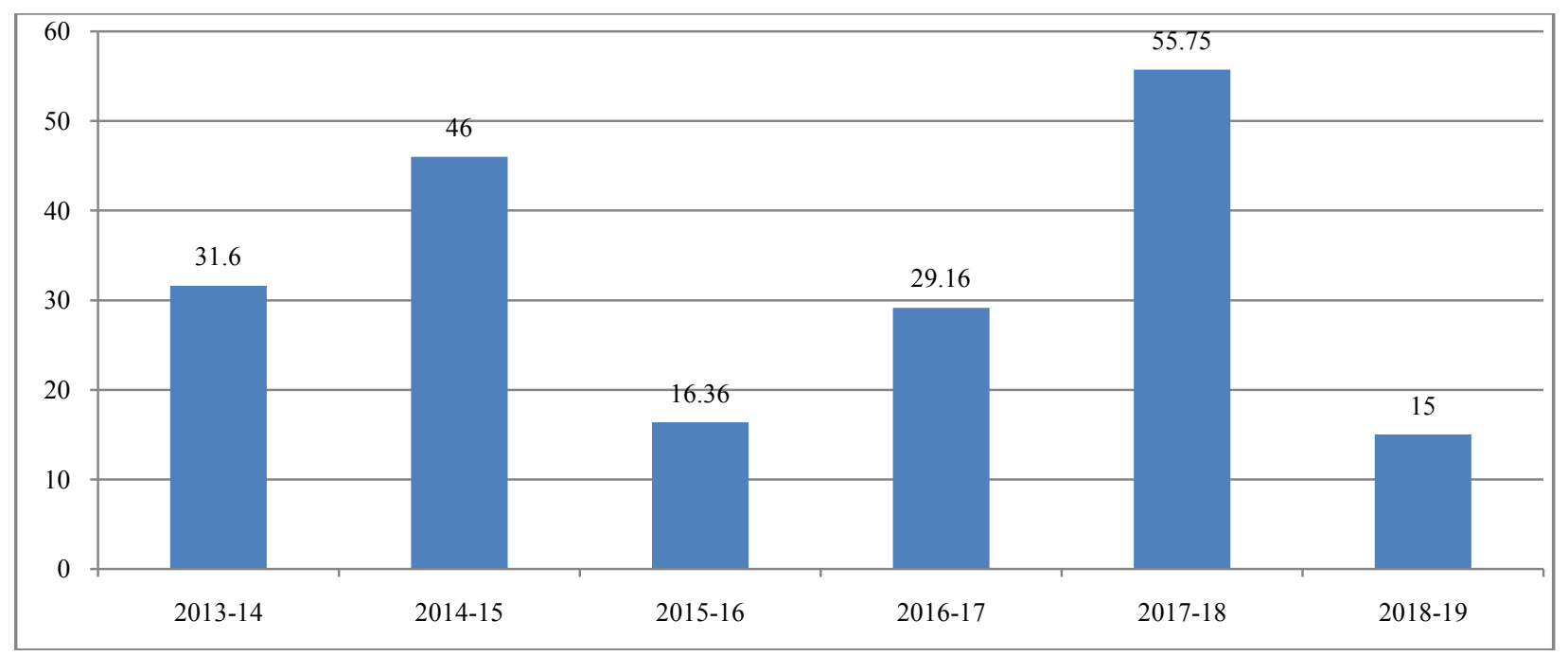

Fig. 2: Percentage of technology Index from 2013-14 to 2018-19

workers, Lalit et al. (2015) and Pradeep Pagaria (2015).

It is clear from the Table 4 per hectare gross returns of ₹ 45507 were obtained in demonstration plots while ₹ 32261 in farmers practices resulting in additional returns of ₹ 13246 . The average net return of ₹ 33274 was obtained in demonstration which was 44.64 percent higher than farmer practices ₹ 23003.66. The B: C ratio was 22.68 percent higher over farmer practices.

The economic analysis made on the basis of prevailing market rates in Table 5 shows that the demonstration gave higher net return of ₹ 10000/ ha, ₹ 31620/ha, ₹ 19400/ha, ₹ 39100/ha, ₹ 24046/ha and ₹ 75480/ha compared to ₹ 5000/ha, ₹ 19220/ha, ₹ 13650/ha, ₹ 22800/ha, ₹ 17720/ha and ₹ 59632/ha under local practices in the corresponding seasons. There was an additional cost of cultivation ₹ 1000 (2011-12), ₹ 1000 (2012-13) ₹ 2300 (2013-14), ₹ 2300 (2014-15), ₹ 1000 (2015-16) and ₹ 650 (2016-17) respectively. Incremental benefit cost ratio was observed $1.95,4.01,2.52,4.20,3.14$ and 4.52 as compared with local check 1.52, 3.06, 2.30, 3.37, 2.70 and 3.72 respectively years. Similar findings 
Table 5: Cost of cultivation, Net return and B: C ratio under improve practices

\begin{tabular}{|c|c|c|c|c|c|c|}
\hline \multirow{2}{*}{ Year } & \multicolumn{2}{|c|}{ Cost of cultivation ( $₹ / h a)$} & \multicolumn{2}{|c|}{ Net Return (₹/ha) } & \multirow{2}{*}{$\begin{array}{l}\text { Additional cost } \\
\text { of cultivation } \\
\text { (₹/ha) }\end{array}$} & \multirow{2}{*}{$\begin{array}{l}\text { Incremental } \\
\text { Benefit cost return }\end{array}$} \\
\hline & Demonstration & Local check & Demonstration & Local check & & \\
\hline $2013-14$ & 10500 & 9500 & 10000 & 5000 & 1000 & $1.95: 1.52$ \\
\hline 2014-15 & 10500 & 9500 & 31620 & 19220 & 1000 & $4.01: 3.06$ \\
\hline $2015-16$ & 12800 & 10500 & 19400 & 13650 & 2300 & $2.52: 2.30$ \\
\hline 2016-17 & 11900 & 9600 & 39100 & 22800 & 2300 & $4.20: 3.37$ \\
\hline $2017-18$ & 11000 & 10000 & 24046 & 17720 & 1000 & $3.14: 2.70$ \\
\hline 2018-19 & 16700 & 16050 & 75480 & 59632 & 650 & $4.52: 3.72$ \\
\hline Mean & 12233 & 10858.33 & 33274.33 & 23003.66 & 1375 & $3.3: 2.77$ \\
\hline
\end{tabular}

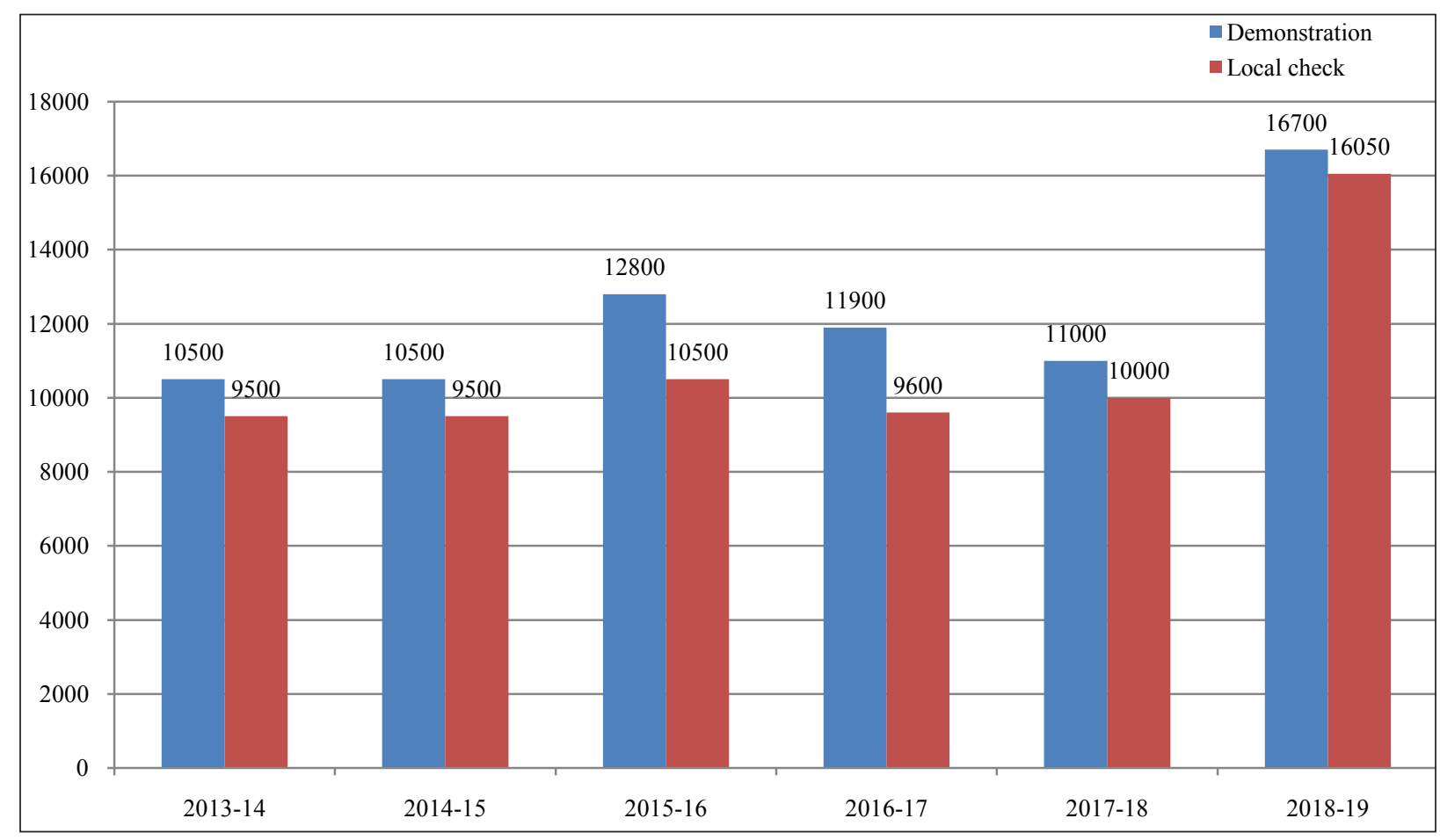

Fig. 3: Cost of cultivation (₹/ha) of green gram under demonstration check as compared with local check

have also reported by Raj et al. (2013) and Chandra Ganesh (2010).

\section{CONCLUSION}

Comparing with local check the noticeable and clearly visible impact of adoption of new agricultural technologies over a period of five years was in yield from $5.89 \mathrm{q} /$ ha to $7.98 \mathrm{q} /$ ha which was $35.48 \%$ higher. It was due the use of improved variety of green gram like TJM-3 (Synchronous Maturity), proper doses of fertilizer $(20 \mathrm{~kg}$. Nitrogen \& $40 \mathrm{~kg}$. Phosphorus per ha), hand weeding plus intercultural operations with hand hoe. The $\mathrm{B}: \mathrm{C}$ ration was 22.68 percent higher over farmer practices. Also in demonstration the average net return ₹/qt 10,270.67 was found to be higher than farmer practices. It won't be wrong to say that green gram production technology has a broad scope for increasing the area and production of Green gram. In shajapur district farming community were motivated after reflection of the better result by new agricultural technologies applied in the FLD plots.

\section{REFERENCES}

Bezbaruah, R. and Deka, R.S. 2020. Impact of Cluster Frontline Demonstration on Productivity and Profitability of Greengram in Morigaon District of Assam. J. Kri. Vigy., 9(1): 164-169. 
AESSRA Raut et al.

Chandra, G. 2010. Evaluation of Front Line Demonstration of Green Gram in Sunderbans, West Bengal. J. Indian Sco. Costal Agric. Res., 28(1): 12-15.

Pagaria, P. 2015. Role of Front Line Demonstration on Transfer of Moong Poduction Technologies in Bermar district Rajesthan. Agric. Update, 10(3): 245-248.

Patil, L.M., Modi, D.J., Vasava, H.M. and Gomkale, S.R . 2015. Evaluation of Front Line Demonstration Programme on Green Gram variety Meha (IPM99-125) in Bharuch district of Gujrat. J. Agric. Veterin. Sci., 8(9): 1-3.

Rai, A.K., Khajuria, S., Lata, K., Jadhav, J.K., Rajkumar and Khadda, B.S. 2016. Popularization of vegetable pigeon pea (Cajanus cajan) in central Gujarat through demonstration in farmers field. Indian J. Agril. Sci., 85(3): 349-353.

Raj, A.D., Yadav, V. and Rathod, J.H. 2013. Impact of Front Line Demonstration (FLD) on the Yield of Pulses. Int. J. Sci. E Res. Public., 3(9): 1-4.
Ray, P., Mandal, S., Mondal, S. and Ankure, P. 2018. Economic Evaluation of Front Line Demonstrations on Black Gram in Birbhum District of West Bengal. Eco. Affairs, 63(2): 521-525.

Sangeetha, R., Ashok, K.R. and Priyanka, P.A. 2020. Scenario of Major Pulse Production in Tamil Nadu: A Growth Decomposition Approach. Eco. Affairs, 65(2): 301-307.

Singh, G., Dhaliwal, N.S., Singh, J. and Sharma, K. 2011. Effect of frontline demonstrations on enhancing productivity of mustard. Asian J. Soil. Sci., 6: 230-33.

Verma, G., Sing, M., Morya, J. and Kumawat, N. 2017. Effect of N,P and Biofertilzers on Growth Attributes and yield of mungbean under semi -arid tract of central India. Int. Archive Appl. Sci. E Tech., 8(2): 31-34. 